UDC 378.147:004

Iryna P. Zadorozhna

Doctor of Pedagogical Sciences,

Professor, Chair of the Department of English Philology and English Language Teaching

Ternopil V. Hnatiuk National Pedagogical University, Ternopil, Ukraine

ORCID ID 0000-0003-1599-1372

irynazadorozhnai@gmail.com

\author{
Anatolii O. Klymenko \\ PhD of Pedagogical Sciences, Associate Professor \\ Department of English Philology and English Language Teaching \\ Ternopil V. Hnatiuk National Pedagogical University, Ternopil, Ukraine \\ ORCID ID 0000-0002-7828-1573 \\ intered_ua@ukr.net \\ Philip Quam \\ Master of Fine Arts, Associate Professor, US Peace Corps Volunteer \\ ORCID ID 0000-0001-8888-0281 \\ pcquam@gmail.com
}

\title{
HYBRID COURSES IN A FOREIGN LANGUAGE AND CULTURE FOR PHILOLOGY STUDENTS
}

\begin{abstract}
Face-to-Face learning is known to involve sessions occurring in traditional classroom settings during the required meeting times. The use of ICT in the given environment is optional and purely supplementary. Online education incorporates a range of asynchronous and synchronous activities to be done by students and teachers not being tied to a strict schedule or same location all the time. Hybrid learning should be treated not only as an opportunity to replace certain portion of traditional in-class activities, but also as a way to make the most out of face-toface and online learning by its capability to meet the needs and purposes of a specific situation, as in the case with students from various countries, especially continents, studying the same course on- and off-line. It is a hybrid course, which to a big extent conforms to the dialectic unity of form and content in present circumstances, especially when it gets to learning foreign languages and cultures, by providing up-to-date educational content in various forms of interactive learning. The article presents the experience of organizing learning through a specially developed study course, which was run at educational institutions in Ukraine and the USA simultaneously within one academic year. The hybrid course is based on a number of approaches, namely: communicative approach (which focuses on learning language and culture through meaningful and real communication), reflective approach (that encourages students to analyze their experience, performance and change behaviour if necessary to improve the outcomes), integrated approach (providing a well-balanced program with extensive input as well as output and interaction practice, with a special focus on cultural issues). Besides main goals and tasks of the course, one of the ideas was to analyze the topical issues included in modules from points of view of both cultures (American and Ukrainian).
\end{abstract}

Keywords: online learning; hybrid education; digital hybrid course; ICT in foreign language and culture teaching.

\section{INTRODUCTION}

The problem statement. The main objective of teaching a foreign language is forming communicative competence, which is accomplished through the use of a complex of approaches, as well as application of relevant methods of teaching in terms of communication and acquiring social standards of verbal and non-verbal behaviour in various situations.

It is undeniable that the application of ICT in education promotes progress in language learning. Besides, it meets the needs of the students, who, according to a recent needs analysis 
survey (Figure 1) done at a number of the Ukrainian universities (83 students representing the Departments of Foreign Languages at Ternopil V. Hnatiuk National Pedagogical University, Khmelnystkyi National University, and Lesya Ukrainka Eastern European National University), claim their preferences and biggest interest in participating in a distance online course with foreign students engaged in it.

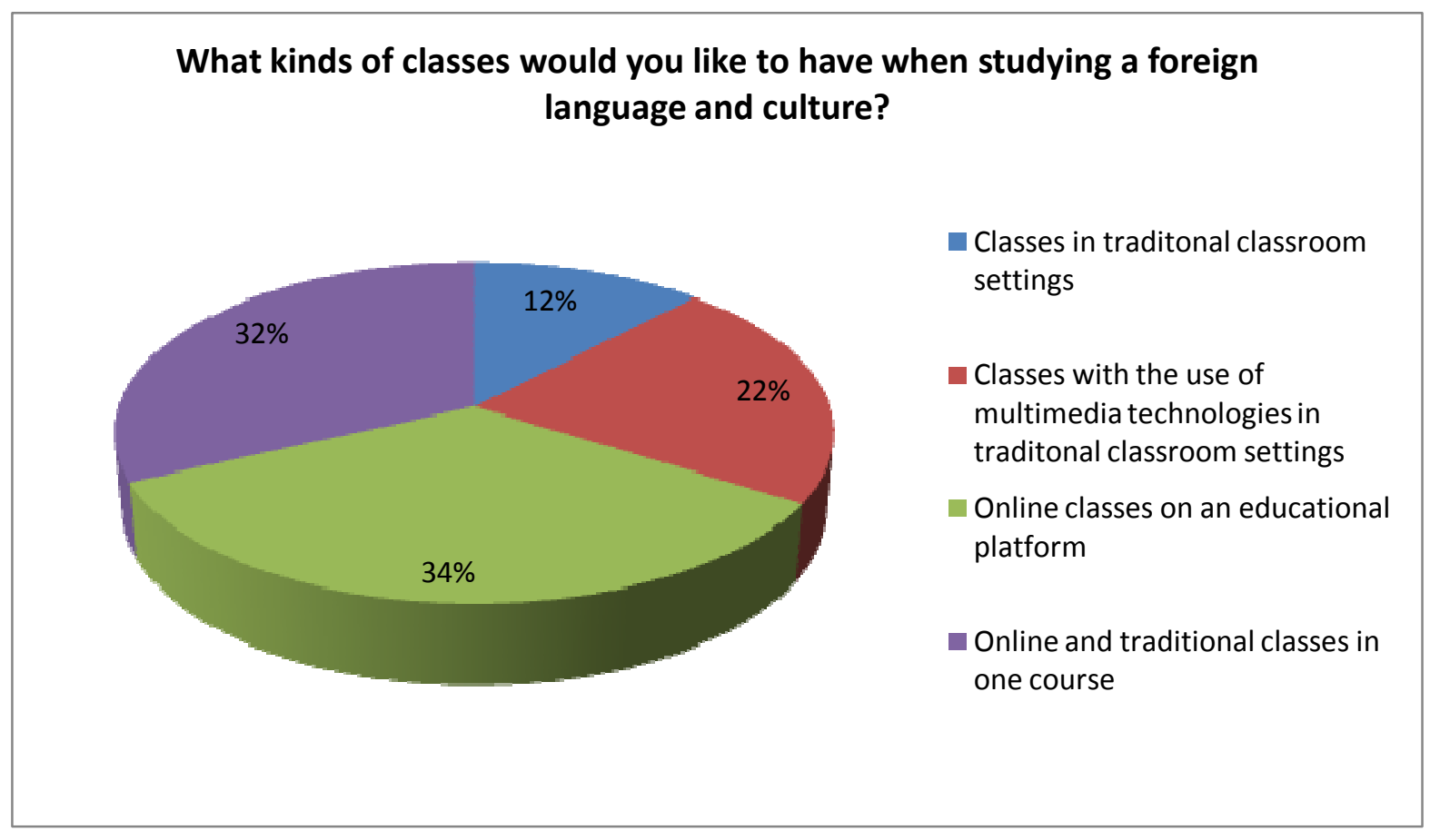

Figure 1. Types of language classes according to the students' needs

Apart from the results of the research shown above, the reality demonstrates a complicated situation, when a lack of technical supplies at educational institutions, resistance from certain teachers to use new technologies in educational process contradict the necessity of moving with the times. In terms of ICT this, for instance, involves transition from face-toface learning to introduction and spread of hybrid education.

Hybrid learning is gradually taking over a prominent, if not yet leading role in the global system of education. Seen to some extent as a combination of face-to-face and distance learning it provides the students and teachers with certain advantages of both. They include flexibility, accessibility, time saving, use of modern technologies, prospects for further learning, collaborative learning, interaction, experienced faculty, etc. It allows participants to make the most of this kind of learning environment, which, for instance, is so much in need in the process of studying such closely connected categories as a foreign language and culture.

Thus, there is a need for a research of features of hybrid courses design, development, management and running with application to foreign languages and cultures teaching and learning via an online educational platform.

The analysis of recent studies and publications. Problems of educational application of ICT have become subject of study for many specialists in the Humanities and sciences. Significant issues regarding organizing and running learning process online are discussed in the works of Ukrainian scholars V. Bykov [1], N. Morze [9], O. Spirin [11], and others.

ICT are being increasingly used in foreign language teaching, giving learners access to information and promoting different types of communication. That is why there have been 
numerous studies on teaching foreign languages with the use of ICT (G. Dudeney [4], N. Hockly [5], G. Stanley [12], A. Walker, G. White [14] and others). Though researchers agree on the positive effects of ICT in a range of educational applications, they all claim the necessity of developing an appropriate pedagogical environment in which ICT is introduced and maintained. In our opinion, this may be provided within a hybrid course, in which various preconditions, conditions, including the requirements, surroundings, similarities and differences concerning arrangements and management are properly utilized.

Theoretical and practical experiences of teaching online via hybrid courses are presented in the works of J. Caulfield [2], R. Clark [3], D. Garrison, N. Vaughan [6], R. Palloff, K. Pratt [10], and others. We considered the ideas of scholars on how teaching and learning online should be properly organized, what problems could be faced in that process, as well as possible ways to solve them. R. Clark [3, 22] describes three e-learning architectures (receptive, directive and guided discovery), that evolved in the past decades. Based on information acquisition, response strengthening, and knowledge construction correspondingly, presupposing respectively low, medium and high inter-activity, they are still used in all kinds of courses available today.

As stated by a number of scientific papers [8; 13], language and culture are intricately related. Language creates meaning only in its cultural context. Learning an additional language involves developing understanding of the cultural context in which communication takes place.

The use of ICT technologies, and in particular online educational platforms, enhances the process of learning a foreign language and culture, since it provides a number of benefits which cannot be obtained in traditional classroom settings. Among them one should mention online face to face communication, working in an international team, distance learning with teachers and students on sites all over the world, access to the necessary information etc.

The objective of this paper is to study theoretical and practical aspects of teaching a foreign language and culture in a hybrid course on an educational online platform with further focus on discussing the results of implementation of digital study course "Global Media: Fact, Fiction, and the Truth with a Capital "T"' into curriculum at Ternopil V. Hnatiuk National Pedagogical University, Ukraine (TNPU).

\section{RESEARCH METHODS}

During the study a number of methods have been used, namely: critical analysis of scientific literature on the problems of teaching language and culture, application of ICT in a university setting to study the experience and determine the progressive ideas to be used for developing the course; system, inductive, deductive approaches to summarise the ideas and make logical conclusions on designing and teaching an online course; interpretation of research results; empirical - questionnaires, interviews, scientific observation in order to determine students' needs and their evaluation of the course.

\section{THE RESULTS AND DISCUSSION}

The introduction of any online course is preceded by a rigorous period of design and development. To a certain extent, the design of the course may be seen as "pre-development" stage, since the steps that are taken at this very point (brainstorming a course, defining learning needs and teaching goals, sketching out the structure and activities, and deciding on technology and tools to fit) are often treated as being more abstract than the ones that are taken during the stage of development, which, in their turn, include more specific actions: 
creating content per module and lesson; writing lesson abstracts, making introductions and summaries to the topics discussed; preparing multimedia presentations, structuring learning activities, developing learning resources, registering a course on an online platform, uploading content, arranging interaction, and finally launching the course.

Designing and teaching a hybrid course should include arranging a student-centred learning environment, setting discussions as a way to study, meeting student expectations, providing participants' feedback, enhancing teaching via application of technology.

Whether design and development are seen as separate stages in creating a study course, in particular, a hybrid one, or as one which is made of two sub-stages, the steps which they include require giving answers to the following questions:

- What do we want our students to learn? It is of great importance to define the right objectives of the course, which along with development of competencies, outcomes, objectives, assessments, in R. Palloff and K. Pratt's opinion [10], must also reflect the institutional mission, i.e. the mission of educational establishment(s), where a course is to be run.

- What are the teaching approaches relevant to the given type of learning?

- What modules, topics are to be studied? In what order should this be done?

- How will learners be assessed? A cornerstone of a course of any kind, assessment, grading scales and criteria are to be planned accurately at the stage of design and development. In addition to traditional grading, which is seen as a way to determine the performance levels for relevant activities, there is also a tendency to involve selfassessment technique, which helps to define strong and weak points of a course in order to cope with the challenges in this regard further on.

- Who is going to participate in classes and other activities?

- Where and when will the students study the course?

- What technology and tools should be used? The last two questions in the list about the location and Internet educational platform comprise other aspects of the environment. This, according to R. Clark $[3,25]$ includes technical constraints of the delivery platform, network itself, software, cultural factors in institutions (familiarity with technology), issues on budget, time, and management expectations.

Let us comment on and provide answers to the above mentioned checking questions in terms of hybrid course "Global Media: Fact, Fiction, and the Truth with a Capital "T", which has been launched at TNPU by Peace Corps Volunteer, Phillip Quam.

The aim of the course "Global Media: Fact, Fiction, and the Truth with a Capital " $T$ ' is to expose Americans to aspects of Ukrainian culture with real Ukrainians within their peergroup, and Ukrainians, likewise, to American culture with Americans similar in age. That is the macroscopic view. If one were to narrow the focus specifically to the Ukrainian students, then the aim of the course is also to expose them to a modern style classroom experience while still honing the four cornerstones of language education: reading, writing, listening, and speaking.

Ukrainian students are supposed to improve language skills considerably. At the end of the course they should be able to follow extended speech with a considerable degree of slang and idiomatic usage even when relationships are not shown explicitly; read a wide range of texts on various topics, identifying the relevant and irrelevant information; participate effectively in extended discussions on personal, cultural, intercultural or social subjects expressing ideas with clarity and precision; make an oral summary of long complex texts; express fluently, spontaneously and accurately orally and in writing. Students are expected to develop appropriate cultural awareness to communicate effectively with native speakers in various contexts and improve digital literacy necessary to succeed in modern world $[15,71-$ 74]. 
The course is based on the ideas of the communicative approach which focuses on learning language and culture through meaningful and real communication; reflective approach that encourages students to analyze their experience, performance and change behavior if necessary to improve the outcomes; integrated approach which provides a wellbalanced program with extensive input as well as output and interaction practice, focus on cultural issues [16].

The structure of the course comprises modules, subdivided into topics. According to developmental approach to teaching, topics are studied by one in a consistent order, so that the students will obtain the knowledge gradually on their way to new themes and more complicated learning and life experiences.

The course contains various topical issues, chronologically and consistently studied within two semesters of a school year. Because the course began the second week of September, the first module was built around the 9-11 terrorist attacks on the World Trade Center in 2001. Since the students, both American and Ukrainian, were toddlers during this atrocity, there was much that they had not seen or read about. Several of the Ukrainian students had in fact never seen the footage of the attack itself and the collapse of the towers, and the simple act of watching it together, reading about that day, and viewing a documentary that followed the chaos proved powerful to them. For the topics that are central to American culture right now - gun laws, gender equality, racism, and so on - it was relatively easy to drum up plenty of material for a module of several weeks.

The examples of modules and their content are illustrated by Figures 2-6.

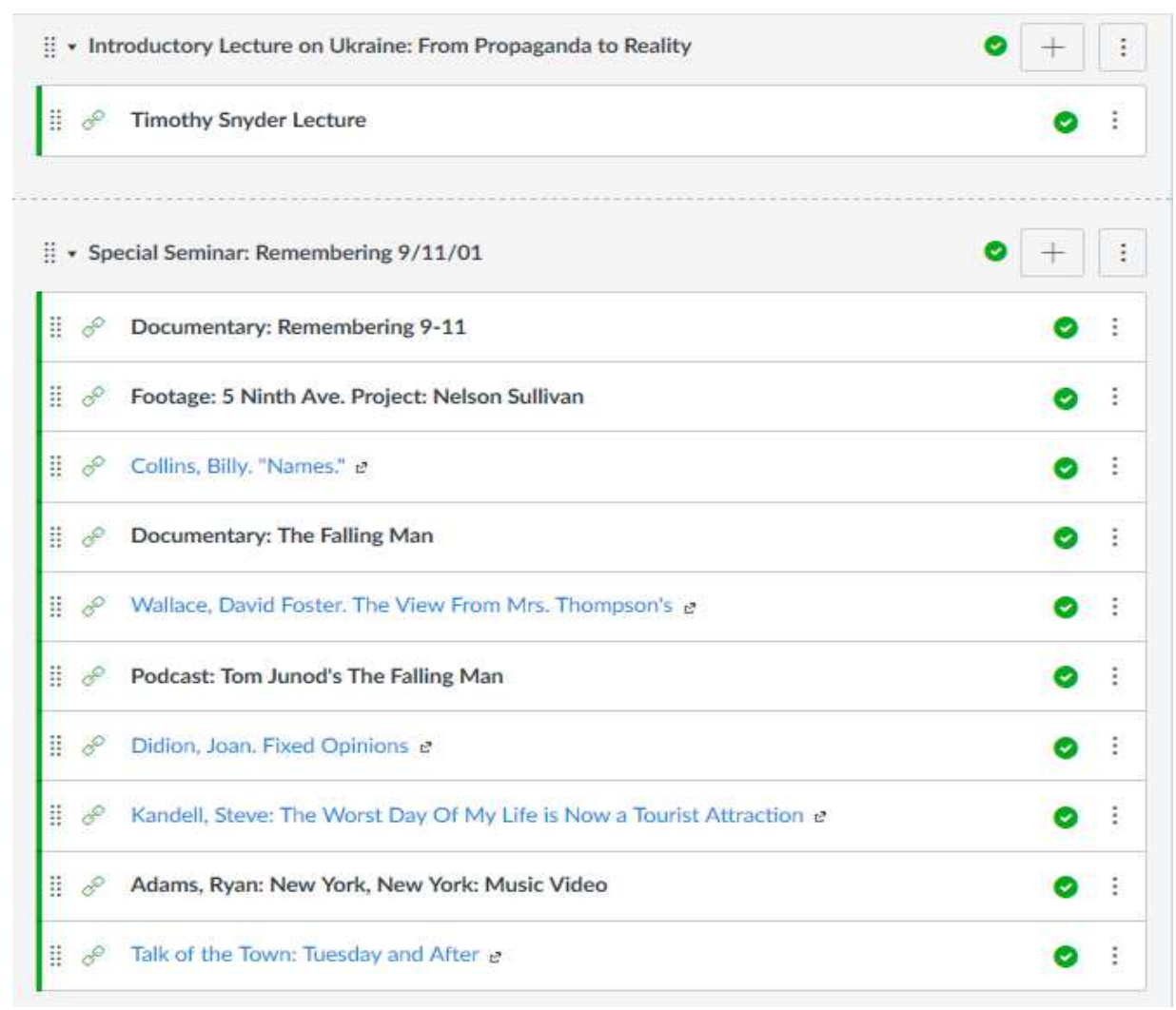

Figure 2. Module 1 "Commemorating 9/11/01" and its activities 


\begin{tabular}{|c|c|c|c|}
\hline \multicolumn{2}{|c|}{ II. Race and Racism } & \multirow{2}{*}{$\frac{+}{0}$} & \multirow{2}{*}{$\begin{array}{l}\vdots \\
\vdots\end{array}$} \\
\hline i: & Dred Scott Court Case or & & \\
\hline \#̊ & Dred Scott (con't) e & $\odot$ & $\vdots$ \\
\hline 泣 & Plessy v. Ferguson o & ○ & $\vdots$ \\
\hline ia & Brown v. Board of Education o: & 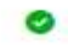 & $\vdots$ \\
\hline$\ddot{1} \infty$ & "Sympathy" by Paul Laurence Dunbar o: & $\odot$ & $\vdots$ \\
\hline i: & "My Mother Dreams Another Country" by Natasha Trethewey o: & $\odot$ & $\vdots$ \\
\hline$\ddot{\vdots} \infty^{\circ}$ & Staples, Brent. "Black Men in Public Space:" 1986 " & ? & $\vdots$ \\
\hline i: 8 & Dickerson, Debra. Who Shot Johnry? is & ? & $\vdots$ \\
\hline i: 8 & "Frederick Douglass" by Robert Hayden ez & $\odot$ & $\vdots$ \\
\hline i: 8 & $\begin{array}{l}\text { Baldwin v. Buckley: A Debate: Is the American Dream at the Expense of the American } \\
\text { Negro? Links to an external site. }\end{array}$ & ( & $\vdots$ \\
\hline$\ddot{\vdots} \infty$ & Baldwin Buckiey (con't) os & (2) & $\vdots$ \\
\hline :i: & Baldwin, James. "Stranger in the Village." From: Notes of A Native Son. 1955 of & $\boldsymbol{0}$ & $\vdots$ \\
\hline i: & King Jr., Martin Luther. "Letter from Birmingham City Jail." 1963. re & $\theta$ & $\vdots$ \\
\hline$\ddot{1} \approx$ & "Ballad of Birmingham" by Dudley Randall is & 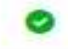 & $\vdots$ \\
\hline$\ddot{1} 20$ & Naylor, Gloria. Mommy. What Does Nigger Mean? of & 0 & $\vdots$ \\
\hline
\end{tabular}

Figure 3. Module "Race and Racism" and its activities

\begin{tabular}{|c|c|c|c|c|}
\hline \multicolumn{2}{|c|}{$\ddot{:} \cdot$ Crime and Punishment } & $\theta$ & + & $\vdots$ \\
\hline : & Paterniti, Michael. "Should We Get Used to Mass Shootings?" GQ. 2016. e & & ○ & $\vdots$ \\
\hline$\ddot{:} \infty$ & Brief History of the NRA: According to the NRA & & ○ & $\vdots$ \\
\hline$\ddot{:} \infty^{\infty}$ & 2nd Amendment: Brief History e & & $\theta$ & $\vdots$ \\
\hline : $\infty^{\infty}$ & TED talk: Sue Klebold: My Son Was a Columbine Shooter & & ○ & $\vdots$ \\
\hline$\ddot{\# \infty}$ & The New York Times. "Stop and Frisk in Brownsville." 2010 e & & $\theta$ & $\vdots$ \\
\hline$\ddot{0} \infty^{\circ}$ & Echols, Damien. "Life After Death," The Moth Radio Hour. 3 May 2017. e & & ○ & $\vdots$ \\
\hline$\ddot{\#} 0^{\circ}$ & Adam Winkler: The Secret History of Guns e & & $\odot$ & $\vdots$ \\
\hline : & Back of Beyond.docx & & ? & $\vdots$ \\
\hline
\end{tabular}

Figure 4. Module "Crime and Punishment" and its activities 


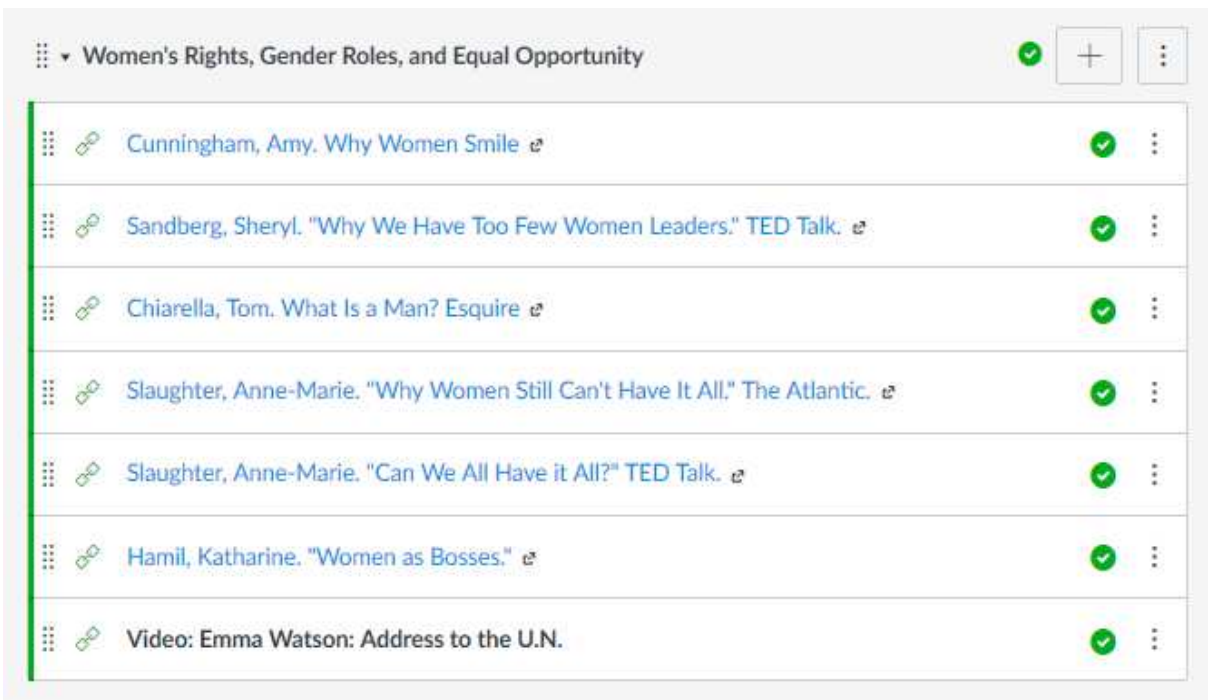

Figure 5. Module “Women's Rights, Gender Roles, and Equality” and its activities

\begin{tabular}{|c|c|c|c|}
\hline \#- Globalization and Its Concerns & 0 & + & $\vdots$ \\
\hline : $\&$ Chayka, Kyle. Welcome to Airspace e & & ○ & $\vdots$ \\
\hline \#\# Baron, Dennis: Is English Safe? e & & ? & $\vdots$ \\
\hline \#: ${ }^{\circ}$ Malik, Kenan: In Defense of Cultural Appropriation e & & ( & $\vdots$ \\
\hline \# Hitchings, Henry. What's the Language of the Future? & & 0 & $\vdots$ \\
\hline \#: Orwell, George. Politics and the English Language $e$ & & ○ & $\vdots$ \\
\hline \# Frontline: Is Walmart Good for America & & $\bullet$ & $\vdots$ \\
\hline \# Stern, David. Ukrainians Fall Out of Love with Europe. Politico 2 & & $\bullet$ & $\vdots$ \\
\hline : ${ }^{\infty}$ The Collapse of the White Working Class: The Atlantic a & & $\bullet$ & $\vdots$ \\
\hline
\end{tabular}

Figure 6. Module "Globalization” and its activities

The design of each module had to meet certain personal criteria. The Canvas platform is very user friendly in this regard. Other modules built included Politics and Immigration; Race and Racism; Women's Rights, Gender Roles, and Equal Opportunity; Crime and Punishment; Euro Maidan: Ukraine's Revolution of Dignity; Globalization and its concerns. Within each of these modules, aside from the two that are country specific, the goal was to take these broad, high-voltage topics and try as best as possible to analyze them from both cultural points of view.

In terms of assessment, within the modules, weekly assignments revolved mainly around the discussion board posts, which were graded on a 20 -point scale. The teachers would post prompts to the readings or videos that sought to have each group member interact with one another (usually two responses to another's post were also required). As expected, weekly responses varied, but in general there was a considerable amount of interaction on the board. Regarding Ukrainian students, they produced real quality work. Each of them, it was clear, 
took their time to produce language as grammatically correct and well-rounded as they could. It was a sense and feeling of achievement for them too about what they reached, and learned, despite the fact, that there was a certain amount of pressure on them, since English is their second language and they did not want to look inept in front of their American peers. This latent motivation is an invaluable tool in the ESL classroom, and this kind of motivation came from within each of them.

Fig. 7-9

The examples of the assignments, which come along with the modules, are illustrated in

\begin{tabular}{l} 
Introductions \\
Please upload a video of yourself in which you state your name, age, and nationality. You may also include \\
something that you'd like to learn about either the US (if a student at TNPU) or Ukraine (if a student at CHC). \\
This topic was locked Sep 22, 2017 at $6: 59 \mathrm{am}$. \\
\hline Search entries or author
\end{tabular}

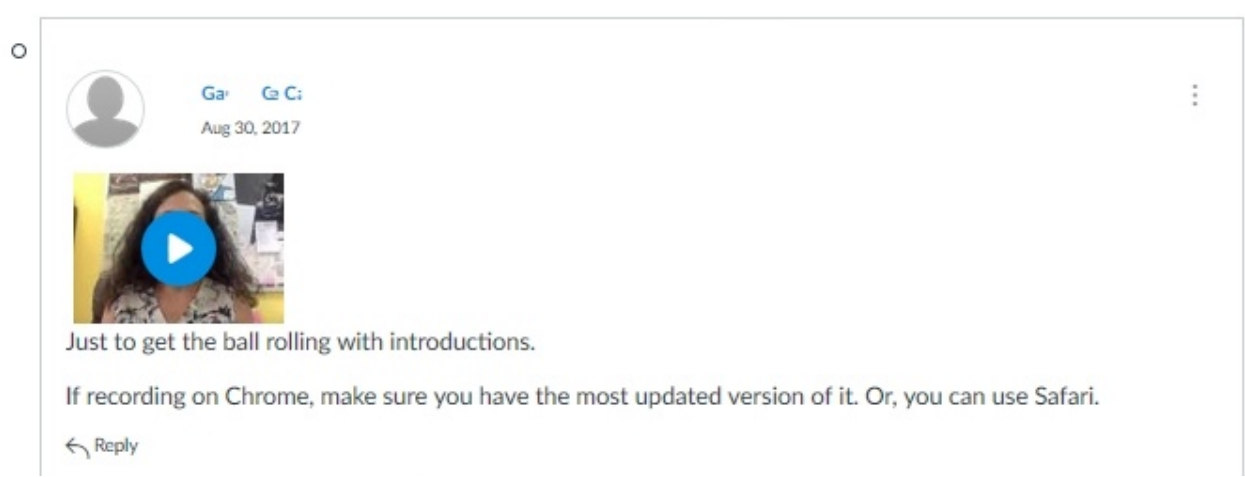

Figure 7. Video assignment for introduction

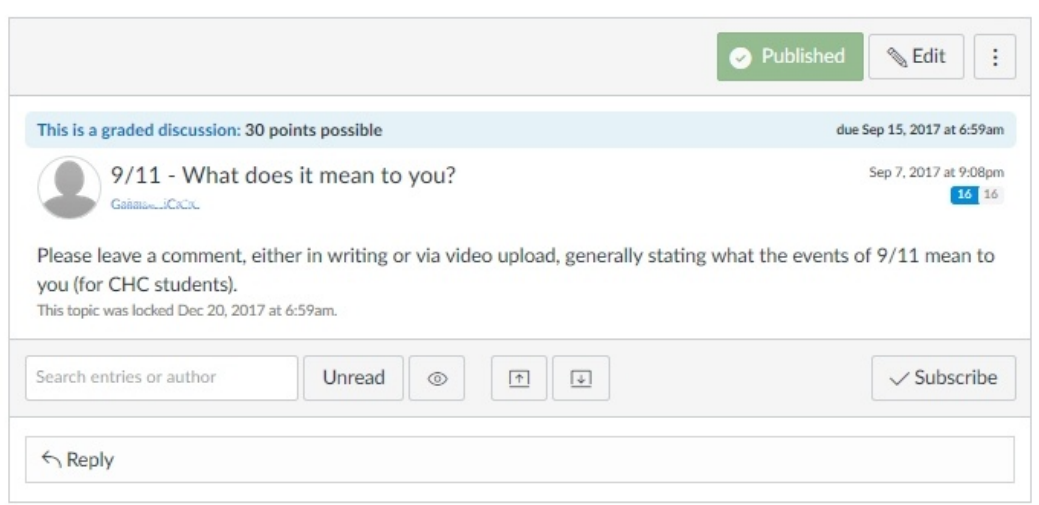

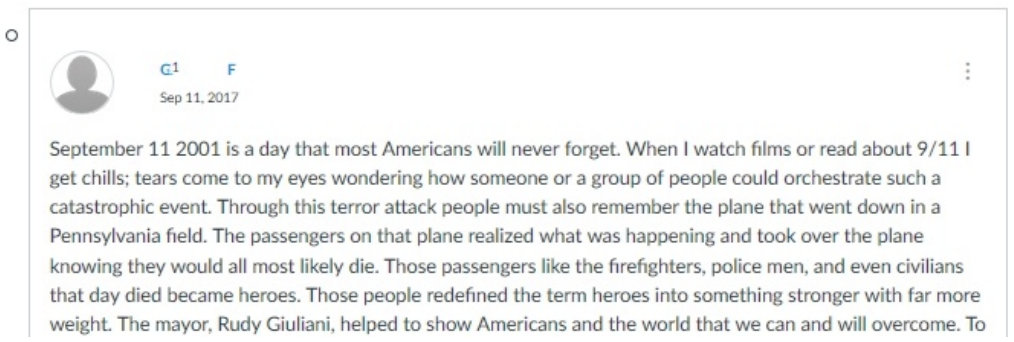

Figure 8. Example of an assignment for module " "Commemorating 9/11/01", 


\section{A Day in the Life of You}

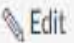

$$
\begin{aligned}
& \text { Please upload a video (using your smartphone or another portable recording device) showing us something typical } \\
& \text { from a day in your life. You can take us to sports practice, play practice, or other after school activities. You can } \\
& \text { take us through a walk in your neighborhood or show us some leisure activities you enjoy at home. You can take us } \\
& \text { on a typical errand, or share a video of some of your favorite places to go in Virginia Beach or Hampton Roads. } \\
& \text { OR, if you are partaking in Rosh Hashanah festivities and would like to share something about them with the class, } \\
& \text { please give us an idea of how your family celebrates. } \\
& \text { Your video should be at least one minute long. }
\end{aligned}
$$

Figure 9. Example of an assignment on cultural and background issues

Beside discussions, the tasks within the course comprised writing essays, comments, and in-person debates. In addition to this, there were a few video post assignments too. For instance, each student (individually or in groups) did a "Day in the Life" assignment in which they filmed a typical school day or their home life - everything from getting ready in the morning, what their classes looked like, introducing other classmates, extracurricular activities, and so forth. The students had fun with this assignment and most of the videos turned out very well. The Ukrainian group came over to a teacher's flat to film a "Ukrainian Cooking Show" in which they made borsch and varenyki (dumplings), and filmed the process. It really seemed to bring them all together as a team. Moreover, they were all using the technology of their phones and cameras to film and edit the videos and upload them to the platform. So, again, it was a productive use of the technology they use daily to intertwine it with class activities.

The last assignment looked like a "flashback". The students were supposed to prepare a presentation on what they learned during the course, their experience and thoughts on the subject.

There were two groups (one from Ukraine and another one from the US) and teachers on both "sides" among the participants of the course.

Considering the time, it was required to arrange it for certain classes to be run synchronously. The chosen time of regular weekly classes was 3:30 pm EET, which was 8:30ET in Virginia, USA. The American group had one class per week, whereas the Ukrainian students had two classes: one with teachers, and sometimes local experts, and another one - with their American peers and experts, online.

The activities in the course involved time spent in classrooms on discussing topics among students of both groups, real time, online, and also doing some assignments outside of classrooms, within one of the groups on different locations. These meetings were called "the field trips".

In terms of technology and tools, it should be mentioned, that it is often a challenge to choose the proper ones in order to be used effectively in certain learning surroundings. Beside the traditional ones which include blackboards, whiteboards, projectors, films and videos, teachers, as in the case of an online course, have to choose an educational platform to run it.

- For the course, Canvas platform was chosen, with its numerous technological and learning tools at teachers' and students' disposal. Students at TNPU, third and fourth years, had laptop access and smartphones, which obviously made their transition into 
a chiefly online course more or less seamless. For course design, the Canvas platform allows one to build topic modules, imbed videos, link articles, upload multimedia presentations, and create discussion boards on which the students can interact with one another each week about a given topic Hardware and software. Technically, the biggest problems were with incompatibility of certain network protocols, used at educational institutions, which resulted in the cases when certain services, tools and equipment at times could not be used. Mostly because of unstable Internet connection, there were days, when Skype discussions could not be properly run, and thus had to be rescheduled a few times.

- Information resources. At times, it was not easy to find enough material from Ukrainian journalism and so on to have the balance needed for Skype discussions. Thus, American culture remained the dominant force driving the debates.

- Timezone difference. It turned out to be a noticeable problem, especially combined with schedule planning. The schedule itself had to conform to the fact that students of the class on both sides of the Globe, as well as within the educational institutions, come from different academic groups and years of study. Also, a compromise was to be found as to the weekdays and the time. Golden medium was reached in the way, that American students had to come 1,5 hours before their classes, and the Ukrainian students had to come approximately 2 hours after their classes.

- Seasonal calendar. The difference in the time and duration of vacations led to certain ramifications as to the tasks fulfillment. As an example, one major assignment that did not come together well was the inter-class project given to the students for their long holiday break, much of this was due to scheduling and time-zone issues. American schools return from their winter holiday shortly after the New Year. However, our group was not scheduled to return to campus until early February. Trying to bridge this gap, a small research project was assigned to each group, which was comprised of both US and UA students. The underlying goal here was, again, to have them interact with each other, negotiate the respective time-zone difference, assign work amongst themselves and produce a brief video presentation. (Each member was to upload his/her own video, based on how the group divided the work.) As it turned out, people sometimes did not respond to text messages, and so on. Each group produced something; however, it was not the level that intra-group work was supposed to be. But, it was worth doing, and gave the chance to reassess how teachers might do something like this in the future.

- Being an obligatory requirement rather than a drawback, and thus in some situations treated as a challenge, the upper-intermediate level of English is needed for the course and project of this kind to be run successfully.

Seeing the course as a continuous process aimed at enhancement of teaching and learning, self-assessment is bound to be made on a regular basis. The following challenges faced during the course should be mentioned in this regard:

The SWOT-analysis and SNW-analysis, which in the research [7] is treated as a part of diagnostic and didactic analysis of the educational process, were conducted. Along with the reflecting and assessing the results of the study and teaching process it allowed us to define the strong and weak points of the course, as well as the potential challenges, and showed the things to be changed in the future regarding this course and kept in mind as for the courses to be developed.

The results of the survey done among the participants of the course after its end prove the efficacy of this project. As for the students, the questions in the survey were based on selfanalysis, and the ones for the teachers grounded on expert evaluation method. Figure 10 illustrates some examples in this regard. 


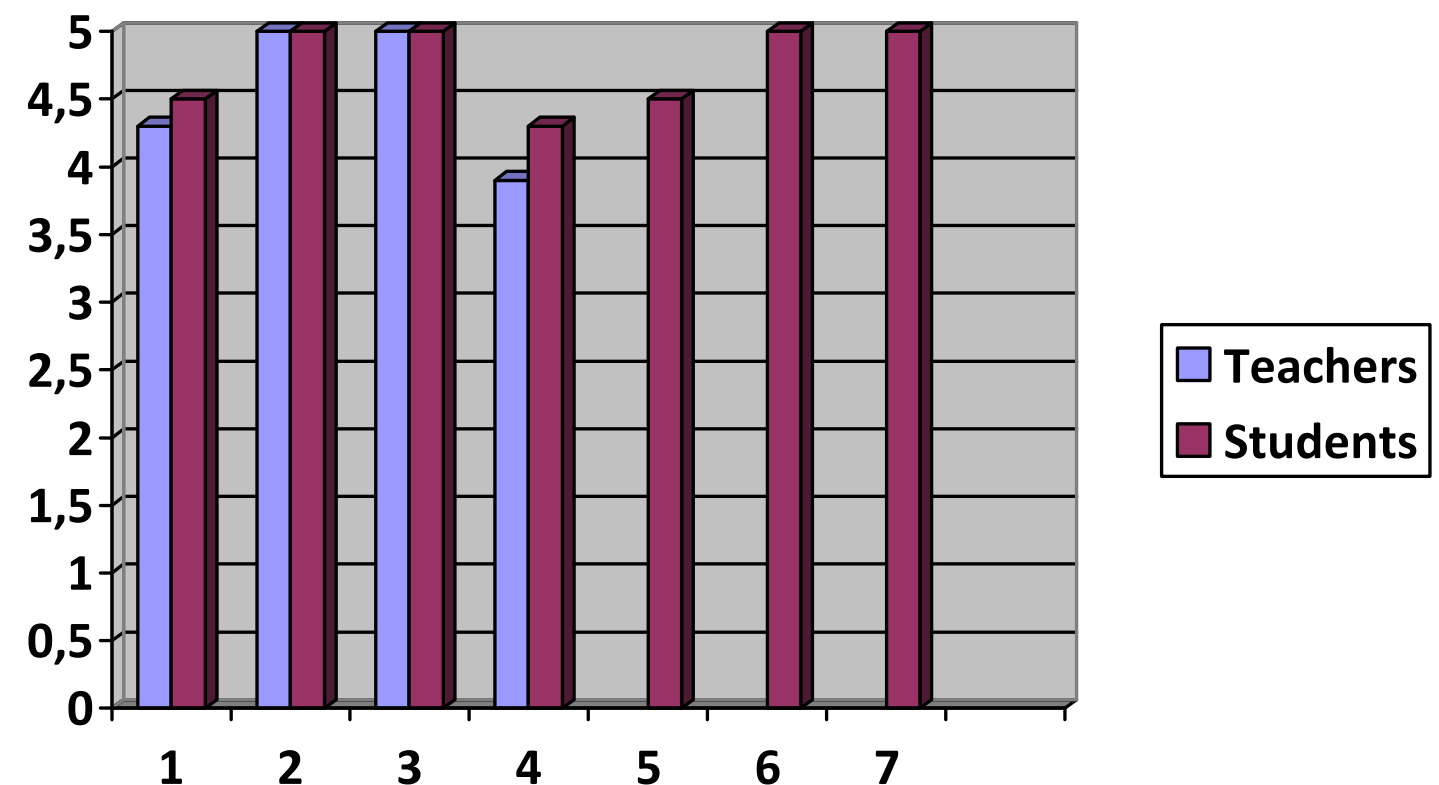

Figure 10. Evaluation of the course by teachers and students

According to the instructions, students and teachers ranked their answers to the questions (1-5), with 1 to be the lowest mark, and 5 - the highest one. Questions demonstrated in Figure 10 are the following:

1) How well was the course organized?

2) How interesting were the studied topics?

3) How interesting and creative were the activities?

4) How well did the communication with other participants go?

5) How would you rank the knowledge, skills and experience you obtained during the course? (for students only)?

6) How would you rank the chance that you would recommend this course to other students? (for students only)?

7) How would you rank the chance that you would apply for any other hybrid course in the future? (for students only)?

\section{CONCLUSIONS AND PROSPECTS FOR FURTHER RESEARCH}

The process of design, development, management and running a hybrid course requires accurate planning, conducting preliminary, ongoing and final analysis with the use of matrix methods, and other forms of self-assessment and grading. It also demands a considerable amount of time and effort to be spent on it.

The course "Global Media: Fact, Fiction, and the Truth with a Capital "T" is an example of how studies of language and culture, academic and cultural communication and cooperation can be organized in a hybrid course, and run simultaneously online and offline at home educational institutions and overseas.

The pros of running such course comprise studying and working internationally, possibility to step outside the traditional classroom settings, new learning and cultural experience, including possibility to communicate with experts coming from different countries, which at present is not widely practised in Ukraine. 
Pitfalls, or the cons, faced in the process of teaching any course should be detected, and avoided or corrected at the first opportunity, when possible. This should be done annually during the course, in case new challenges arise, and before its beginning.

Reflecting after this first year of the course "Global Media: Fact, Fiction, and the Truth with a Capital " $T$ "", despite some inevitable stumbles along the way, running it, by all measures, was a success. The overarching goals of inter-cultural exchange of ideas and cooperation were achieved. Something which cannot be accurately measured is the fact, that with the proliferation of social media and the fluidity with which the students of the course communicate now, they will ostensibly follow each other through their college experiences and perhaps beyond. Something like that is not quantifiable - nor, as we think, should it be.

What has already become a tradition in many projects of international studies, the groups usually meet after the end of the course, which, without exaggeration, often plays a significant role in their lives as students and future professionals. We are looking forward to having such a meeting of all of the participants of the course. Because of certain issues we believe this to happen in one of the neighbouring European countries in the nearest future.

We expect the course to be run further on at TNPU, now with new groups of students, one representing Ukraine and another one, or several ones representing other countries and cultures.

In terms of the perspectives of further research we suggest that further investigation of studies of languages and culture in the form of digital courses with the use of ICT should be made. In our opinion, in its turn this would provide additional background for new ideas, courses, experiments, and scientific papers.

\section{REFERENCES (TRANSLATED AND TRANSLITERATED)}

[1] V. Bykov, Organizational System Models of Open Education, 1st ed. Kyiv: Atika, 2009. (in Ukrainian)

[2] J. Caulfield, How to Design and Teach a Hybrid Course, $1^{\text {st }}$ ed., Stylus Publishing, LLC, 2011. (in English)

[3] R. Clark and R. Mayer, E-Learning and the Science of Instruction, $3^{\text {rd }}$ ed., Pfeiffer, 2011 (in English)

[4] G. Dudeney, The Internet and the Language Classroom: A Practical Guide for Teachers, 2nd ed., Cambridge University Press, 2007. (in English)

[5] G. Dudeney and N. Hockly, How to Teach English with Technology, Pearson Longman, 2008. (in English)

[6] D. Garrison and N. Vaughan, Blended Learning in Higher Education. Framework, Principles, and Guidelines, $1^{\text {st }}$ ed., Jossey-Bass, 2008. (in English)

[7] A. Klymenko, "The Use of matrix methods of analysis in informational activity of a modern university teacher of foreign languages”, Naukovi zapy`sky`Ternopil`s`kogo nacional’nogo universy`tetu imeni Volody 'my`ra Gnatyuka. Seriya: pedagogika,vol. 4, 2016. (in Ukrainian)

[8] C. Kramsch, Language and Culture: Oxford University Press, 1998. (in English)

[9] N. Morze and A. Kocharian, "ICT competence standards for higher educators and quality assurance in education", Information Technologies and Learning Tools, vol.43, no. 5, 2014. (in Ukrainian)

[10] R. Palloff and K. Pratt, Assessing the online Learner, $1^{\text {st }}$ ed., Jossey-Bass, 2009. (in English)

[11] O. Spirin, Y. Nosenko and A. Iatsyshyn, "Current requirements and contents of training of qualified scientists on information and communication technologies in education", Information Technologies and Learning Tools, vol. 56, no. 6, 2016. (in Ukrainian)

[12] G. Stanley, Language Learning with Technology: Ideas for Integrating Technology in the Classroom, Cambridge University Press, 2013. (in English)

[13] M. Stubbs. Text and Corpus Analysis: Computer-assisted studies of language and culture. [online]. Available: https://www.uni-trier.de/fileadmin/fb2/ANG/Linguistik/Stubbs/stubbs-1996-text-corpus-ch1.pdf (in English)

[14] A. Walker and G. White, Technology Enhanced Language Learning: Connecting theory and practice, 1st ed., Oxford University Press, 2013. (in English)

[15] I. Zadorozhna, Organization of prospective English teachers' self-study on practical language training. Ternopil Volodymyr Hnatiuk National Pedagogical University, 2011. (in Ukrainian) 
[16] I. Zadorozhna, Reflective foreign language teaching and learning of university students, Naukovi zapy`sky' Ternopil`s`kogo nacional’nogo universy`tetu imeni Volody`my`ra Gnatyuka. Seriya: pedagogika, vol. 4, 2017. (in English)

\title{
ГІБРИДНІ НАВЧАЛЬНІ КУРСИ 3 ІНОЗЕМНОЇ МОВИ ТА КУЛЬТУРИ ДЛЯ СТУДЕНТІВ ФІЛОЛОГІЧНИХ СПЕЦІАЛЬНОСТЕЙ
}

\author{
Задорожна Ірина Павлівна \\ доктор педагогічних наук, професор, \\ ORCID ID 0000-0003-1599-1372 \\ irynazadorozhnai@gmail.com

\section{Клименко Анатолій Олегович} \\ ORCID ID 0000-0002-7828-1573 \\ intered_ua@ukr.net

\section{Філіп Квом} \\ магістр, волонтер Корпусу Миру США \\ ORCID ID 0000-0001-8888-0281 \\ pcquam@gmail.com
}

завідувач кафедри англійської філології та методики навчання англійської мови

Тернопільський національний педагогічний університет ім. В. Гнатюка, м. Тернопіль, Україна

кандидат педагогічних наук, доцент кафедри практики англійської мови та методики ії викладання Тернопільський національний педагогічний університет ім. В. Гнатюка, м. Тернопіль, Україна

\begin{abstract}
Анотація. Традиційне навчання реалізується в умовах класно-урочної системи. Використання IКТ за таких обставин $є$ необов'язковим і зазвичай додатковим. Освіта онлайн включає ряд асинхронних та синхронних видів діяльності, які повинні виконувати студенти та викладачі, не обмежені чітким розкладом або ж постійним місцем проведення занять. Гібридне навчання слід трактувати не лише як можливість заміни певних традиційних видів діяльності на занятті, а й також як спосіб максимально використати потенціал традиційного та онлайн-навчання, що здатний задовольняти потреби та цілі конкретної ситуації, як у випадку із студентами з різних країн, континентів, котрі вивчають один і той же курс онлайн і офлайн. Саме гібридний курс значною мірою відповідає діалектичній єдності форми та змісту в сучасних умовах, особливо коли йдеться про вивчення іноземних мов та культур, шляхом забезпечення сучасного освітнього контенту в різноманітних формах інтерактивного навчання. У статті представлено досвід організації навчання через спеціально розроблений курс, який викладався у ЗВО України та США одночасно протягом навчального року. Гібридний курс грунтується на низці підходів, а саме: комунікативному підході (який зосереджується на вивченні мови та культури шляхом залучення значущих та реальних ситуацій спілкування), рефлексивному підході (що заохочує студентів аналізувати свій досвід і ефективність навчання та змінювати поведінку у випадку необхідності покращення результатів), інтегрованому підході (який забезпечує збалансованість програми, що передбачає оволодіння значущою інформацією та активне їі використання в процесі взаємодії з особливим акцентом на питаннях культури). Окрім основних цілей та завдань курсу однією з ідей було проведення аналізу актуальних питань, що входять до модулів, з поглядів двох культур (американської та української).
\end{abstract}

Ключові слова: навчання онлайн; змішане навчання; гібридний навчальний курс; IКТ у викладанні іноземної мови і культури. 


\title{
ГИБРИДНЫЕ УЧЕБНЫЕ КУРСЫ ПО ИНОСТРАННОМУ ЯЗЫКУ И КУЛЬТУРЕ ДЛЯ СТУДЕНТОВ ФИЛОЛОГИЧЕСКИХ СПЕЦИАЛЬНОСТЕЙ
}

\author{
Задорожная Ирина Павловна \\ доктор педагогических наук, \\ профессор, заведующая кафедрой английской филологии и методики обучения английскому языку \\ Тернопольский национальный педагогический университет им. В. Гнатюка, г. Тернополь, Украина \\ ORCID ID 0000-0003-1599-1372 \\ irynazadorozhnai@gmail.com
}

\section{Клименко Анатолий Олегович}

кандидат педагогических наук, доцент кафедры английской филологии и методики обучения английскому языку

Тернопольский национальный педагогический университет им. В. Гнатюка, г. Тернополь, Украина ORCID ID 0000-0002-7828-1573

intered_ua@ukr.net

\section{Филип Квом}

магистр, волонтер Корпуса Мира США

ORCID ID 0000-0001-8888-0281

pcquam@gmail.com

\begin{abstract}
Аннотация. Традиционное обучение реализуется в условиях классно-урочной системы. Использование ИКТ при этом является необязательным и обычно просто дополнительным. Образование онлайн включает ряд асинхронных и синхронных мероприятий, которые должны выполнять студенты и преподаватели, не будучи ограниченными строгим графиком или постоянным местом проведения занятий. Гибридное обучение следует рассматривать не только как возможность замены определенной части традиционной деятельности в классе, но также как способ максимально использовать потенциал традиционного и онлайн-обучения благодаря своим возможностям удовлетворять потребности и цели конкретной ситуации, как в случае со студентами разных стран, континентов, которые изучают один и тот же курс онлайн и оффлайн. Именно гибридный курс в значительной степени соответствует диалектическому единству формы и содержания в современных условиях, особенно когда речь идет об изучении иностранных языков и культур, путем обеспечения современного образовательного контента в различных формах интерактивного обучения. В статье представлен опыт организации обучения через специально разработанный курс, который преподавался в УВО Украины и США одновременно в течение учебного года. Гибридный курс основывается на ряде подходов, а именно: коммуникативном подходе (который сосредоточивается на изучении языка и культуры путем использования значимых и реальных ситуаций общения), рефлексивном подходе (поощряющем студентов анализировать свой опыт и эффективность обучения, а также менять поведение в случае необходимости улучшения результатов), интегрированном подходе (обеспечивающем сбалансированность программы через овладение значимой информацией, а также активное ее использование в процессе взаимодействия с особым акцентом на вопросах культуры). Кроме основных целей и задач курса, одной из идей было проанализировать актуальные вопросы, включенные для изучения в модулях, с точек зрения двух культур (американской и украинской).
\end{abstract}

Ключевые слова: обучение онлайн; смешанное обучение; гибридный учебный курс; ИКТ в преподавании иностранного языка и культуры.

\section{(cc) EY-NC-SA}

This work is licensed under Creative Commons Attribution-NonCommercial-ShareAlike 4.0 International License. 